a powerful growth.stimulating hormone for Str. hermolyticus. Ite was able to demonstrate a marked reduction in the 'lag phase' during the growth of this bacterium in beef infusion broth to which had been added $0 \cdot 1$ per cent beet juico. Since beets are a rich natural source of glutamine, the connexion is suggestive.

In an attempt to grow the freshly isolated strain of Str. hermolyticus in a medium of completely defined chemical composition, including glutamine, the peptone in McIlwain's medium was replaced with an amino-acid mixturo (Fildes") frecutently used in this laboratory for nutritional studies. No growth was obtained under theso conditions, nor was growth observed when the peptone was replaced with acidhydrolysed casein. In view of theso findings, it scems likely that there is present in peptono another factor (or fnctors) which must be arailable beforo freshly isolated strains of Str. hermolyticus can bo cultivated in a medium of known ehemical composition.

General Biochemicals, Inc. Maurice LaNiny.

I)ivision of John Wyeth and I3rother, Inc., C'leveland, Ohio.

$$
\text { July } 20 .
$$

Ifllwain, II., Fildes, l'., Gladstone, (9. I., and hinight, B. C. J. G. Biochem. $J, 33,0.0 .3(19: 39)$.

- Vickers, II. B.. l'ucler, G. W., and ('lark, H. E., J. Biol. Chem, $109,39(19: 3 \bar{j})$

Dart, F. F., l'roc. Sur. Exp. Bisl. Medl., 32, 3G:3 (1931).

- Fildes, R., Richardoon, G. M.. Kniglit, H. C. J. G., and Gladstonr. (i. I'., Brit. J. Erp. I'ath., 17, ts1 (1936).

\section{Nature of a Group in Papain Essential to its Activity*}

Much of the literature on the activation and inactivation of papain ${ }^{1,2,3,2}$ supports the hypothesis that thero is an essential SH group in the active enzyme.

The active erystalline eny.mes, however, does not give a positive nitroprussicle test or a satisfactory titration with porphyrindin ${ }^{6}$. Crystalline papain, like certain ot her proteins, was observed to give a positive nitropruside test in the absence of cyanide only after denaturation. If, however, the native protein Was first innctivnted with jodoacetate, then separated from the excess of iodoacetute by precipitation with salt and finuly denutured as before, no nitroprusside test without cyanide was obtained. In agreement with this observation, hydriodic acid was detected in the mother liquor from tho salt precipitation. 'Titration of the denatured protein in urea solution by iodino gave results which indicate that only one sulphur group (of about ten in tho papain molecule) is involved and that it disappears when the enzyme is innctivated by iodoacetute or cystine. This is supported by the observation that inhibition of papain netivity is produced by one molecular eçuivalent of iodoacetate. Papain is still 'nutive' after reaction with cystine; that is, the solubility is apparently unaltered and the protein cun still be crystallized.

It may be concluded that the SHI group that appears on denaturation is blocked from reaction with some but not with all reagents while the protein is in the native stute. Dr. M. I. Anson informed us by private commmication that ho has observed that SH groups in certain proteins react withiodoacetamide, but nre not attaclied by oxidizing agents.

- Food lescarcli contribution No. \$4.
Results of titrating denatured papain SH groups with iodine are shom in the accompanying table :

\begin{tabular}{|c|c|c|c|c|c|}
\hline \multirow{2}{*}{$\begin{array}{l}\text { Enzyme } \\
\text { propiara- } \\
\text { tion }\end{array}$} & \multirow{2}{*}{$\begin{array}{l}\text { Treatment } \\
\text { of protein }\end{array}$} & \multicolumn{2}{|c|}{$\begin{array}{l}\text { Eipuivalents of } \\
\text { protein } \times 10^{\prime}\end{array}$} & \multirow{2}{*}{$\begin{array}{l}\text { Fipuiva: } \\
\text { lents of } \\
\text { sulpluyiryl } \\
\times i 0^{*}\end{array}$} & \multirow{2}{*}{$\begin{array}{l}\text { SH per } \\
\text { cquivinlent } \\
\text { of active } \\
\text { protcin }\end{array}$} \\
\hline & & Total & Active & & \\
\hline A. & $\begin{array}{l}\text { Pone } \\
\text { Iotoacetate }\end{array}$ & $\begin{array}{l}37 \\
37\end{array}$ & $\begin{array}{r}30 \\
2\end{array}$ & $\frac{28}{5}$ & $0 \cdot 93$ \\
\hline $\begin{array}{l}A \\
A\end{array}$ & $\begin{array}{l}\text { Pone } \\
\text { Iodoraterte }\end{array}$ & $\begin{array}{l}19 \\
19\end{array}$ & $\begin{array}{r}15 \\
1\end{array}$ & 17 & $1 \cdot 13$ \\
\hline $\begin{array}{l}\text { I3 } \\
13 \\
\text { 13 } \\
13\end{array}$ & $\begin{array}{l}\text { Xone } \\
\text { C'ytine } \\
\text { lystine } \\
\text { lodonectate }\end{array}$ & $\begin{array}{l}32 \\
32 \\
31 \\
31\end{array}$ & $\begin{array}{l}2: 3 \\
10 \\
i\end{array}$ & $\begin{array}{l}27 \\
11 \\
11 \\
2\end{array}$ & $\begin{array}{l}1 \cdot 17 \\
1 \cdot 1 \\
1.5 \\
-\end{array}$ \\
\hline
\end{tabular}

'The equivalents of protein are calculaterl using a molecular weight of $30,000^{7}$. The en\%ymo prepara tion treated with iodoacetato contained 21 milk clotting ${ }^{7}$ units of papain per mgin. of protein nitrogen when activated with cyanide, and the one treated with both cystine and iodoacetate contained 27 units.

After the native protein had been freed of the 5-10 fold excess of iodoacetate or the excess of solid cystine, it was denatured by heating at $70-75^{\circ} \mathrm{C}$. for 10 minutes. Tho protein was cent rifuged out, washed and finally dissolved in strong urea solution. This solution wus treated essentially by the method described by Lavines for the estimution of eystine except that the temperature was $0-5^{\circ} \mathrm{C}$. 'The sodium thiosulphat o solution was $0.01 \mathrm{~N}$. The blanks agreed to within $0.02 \mathrm{ml}$.

A. K. B.ILLS.

HaNe LINEWEAVER.

Food Research Division,

Bureau of Agricultural Chemistry and Engineering.

U.S. Department of Agriculture, Washington. July 25.

' lipnis, T., Eiry. Kinzymiforsch.. 4, (is (19:3i).

- IIcllerman, Le, Physiol. Rer. 17, tit (193i).

sanapathy, C. V., and Sastri, 13. N., Saterf, 142, 539 (19:35).

- Jorgan, E. J., and Friedman, K., Bischem. J., 32, 86i2 (19:38).

s Jalls. A. K. J.incweaver, H., and Thompron, R. R., Science, 86, $3 \div 9(1937)$.

- (irecnstein, J. P., J. Niol. Chent., 125, 501 (1933).

'IBalls, A. K., and Lincweaver, II., J. Biol. Chem., in the jress.

- Ialvine, T. F', J. Biol. Chem., 100, $1+1$ (19:35).

\section{Glutamic Acid as a Hydrogen Carrier in Animal Tissues}

It has previously been shown that $\alpha$-ketonic acids liberate carbon dioxide when added to animal tissues under anaerobic conditions ${ }^{2}$. The ovolution of carbon dioxide was found to be due to a 'dismutation'.

(1) $2 \mathrm{r} . \mathrm{CO} . \mathrm{COOH}+\mathrm{Ir}_{8} \mathrm{O}-\mathrm{R} . \mathrm{CH}(\mathrm{OH}) \cdot \mathrm{COOH}+\mathrm{R} \cdot \mathrm{COOH}+\mathrm{CO}_{2}$.

We hnve now found that the annerobic carbon dioxide formation from $\alpha$-ketoglutaric acid in kidney and in heart muscle is greatly increased by the addition of ammonium chloride. The analysis of this effect showed that $\alpha$-ketoglutaric acid 'dismutes' with $\alpha$-iminoglutaric acid (which arises on addition of ammonium salt to $\alpha$-ketoglutaric acid $)^{2}$ as follows :

(2) $\mathrm{COOH} \cdot\left(\mathrm{C}_{3} \mathrm{H}_{2} \cdot \mathrm{CO} \cdot \mathrm{COOH}+\right.$

$$
\begin{aligned}
& \text { (a-ketoglutaric acld) } \\
& \left(\mathrm{OOHI} \cdot\left(\mathrm{CH}_{3}\right)_{2} \cdot \mathrm{CH}:(\mathrm{NH}) \cdot \mathrm{COOH}+\mathrm{H}_{3} \mathrm{O}\right. \\
& \text { a-iminozlutaric acid) } \\
& =\mathrm{COOH} \cdot\left(\mathrm{C}_{8}\right)_{2} \cdot \mathrm{CH}\left(\mathrm{NH}_{8}\right) \cdot \mathrm{COOHI}+ \\
& \text { (glutamic acid) } \\
& \mathrm{COOH} \cdot\left(\mathrm{CH}_{2}\right)_{2} \cdot \mathrm{COOH}+\mathrm{COO}_{2}
\end{aligned}
$$

